\title{
RURAL AREAS OF POLAND AS THE BENEFICIARY OF EUROPEAN UNION FUNDING 2007-2013(15) FOR CULTURAL PROJECTS
}

\author{
Halina Powęska, PhD, post doctoral degree, Senior Researcher ${ }^{1}$ \\ Faculty of Economic Sciences, Warsaw University of Life Sciences - SGGW
}

\begin{abstract}
The paper presents the issues relating to the use of EU funds for cultural heritage projects in rural areas in Poland in the years 2007-2015. The study examines the structure of the funding of EU cultural heritage projects by the purpose of their implementation including revaluation of cultural heritage objects, creation and development of a new tourism product, renovation of sports and recreation infrastructure, promotion and other issues. The spatial analysis was carried out at the level of voivodships. The survey was conducted using the database of the National Information System of the Ministry of Infrastructure and Development of the Republic of Poland (NIS SIMIK 07-13) as at 31 December 2015. In the years 2007-2015, in both rural areas and rural districts, in the case of those projects which were aimed at developing infrastructure and restoring cultural heritage assets, while projects thematically related to the creation of a new tourism product and promotion were of lesser importance. However, the highest grants from EU sources were provided for projects thematically related to the reconstruction of cultural heritage and creation of tourism products, which shows that the activities aimed at preservation of cultural heritage and support for local entrepreneurship are of particular significance to European entities.
\end{abstract}

Keywords: rural areas of Poland, EU structural funds, cultural heritage JEL codes: Z32, Z19, P48

\section{INTRODUCTION}

Social and economic development of rural areas in Poland is conditioned by a number of determinants which show the growing importance of culture (Hełpa-Liszkowska, 2013). Taking into account the definition of culture as a human lifetime achievement transmitted from generation to generation, it is worth noting that the way of conducting the rural economy is also a factor that shapes culture (Act of 15 February 1962). Thus, rural areas use and should use those resources which they produced in the earlier period. Cultural landscape, while preserving its harmonious character, comes to be an important factor of the location of business activity in rural areas (Cawley and Gillmor, 2008; Gralak, 2009; Murzyn-Kupisz, 2012; Ilczuk, 2014). Thus, cultural assets enable the preservation of identity, but at the same time, which is increasingly emphasized, they provide basis for economic development (MacDonald and Jolliffe, 2002). Cultural legacy therefore becomes an element of competitiveness of territorial self-government units; at the same time, however, it constitutes a major financial challenge for the present heads of communes and districts in connection with the maintenance of historic objects and traditions of the regions. That is

${ }^{1}$ Corresponding author: Nowoursynowska 166, 02-787 Warsaw, Poland, halina_poweska@sggw.pl, +4822 5934072 
why EU financial resources, which are used to finance projects aimed at the restoration of cultural heritage assets, are essential for local authorities.

The aim of the paper is to present the ways of spending EU funds allocated for the purposes related to cultural heritage assets located in rural areas and rural districts in Poland. The paper summarizes a series of works which discuss the issue of the use of EU funds for cultural purposes in rural areas against a background of other spatial categories: capitals of voivodships, health resorts and towns with county rights (Powęska, 2016; Gralak and Powęska, 2017). The focus of the paper is on rural communes and small towns, which are jointly considered as rural areas, as well as rural districts, which are treated as the units functionally linked to traditions and rural areas (Courtney and Errington, 2000; Kałuża, 2011; Heffner, 2016; Biczkowski, 2016; Pondel, 2017). A detailed content-related analysis conducted in this article takes into consideration the total value and the amount of EU funding with reference to rural areas and rural districts compared to other spatial categories across voivodships.

The study covered the period $2007-2015^{2}$. In order to achieve our main goal, the following research tasks were identified: (1) to define the share of rural areas and rural districts in the total value and in the level of co-funding from EU resources for 'cultural' projects in the particular voivodships, (2) to show diversity between voivodships in terms of the absolute value as well as in respect of EU funding for culturerelated projects implemented in rural areas and rural districts, (3) to examine the structure of objectives pursued in rural districts and in rural areas in the particular voivodships.

\section{METHODOLOGICAL ASSUMPTIONS}

The study was conducted using data collected in the SIMIK database of the Ministry of Infrastructure and Development of the Republic of Poland for projects financed from European Union structural funds and implemented in Poland during the period 2007-
$-2013(2015)$ as at 31 December $2015^{3}$. As indicated in the previous articles, although during that time the source of financing of projects thematically related to culture was seldom used in Poland (only 1.6\% of all agreements), however, despite their small share in the total amount of EU aid funds, they had a significant impact on the cultural space of the regions.

European projects thematically related to culture were carried out under four Operational Programmes: Infrastructure and Environment, Human Capital, Innovative Economy and Technical Assistance. The projects analysed in this paper also comprise 'cultural' projects implemented during the period 2007-2015 under the Voivodship Regional Programmes. The analysis conducted in this study takes into consideration the following characteristics of the projects: thematic scope, total value and the amount of EU funding, as well as an area of project implementation. On the basis of the thematic scope of the projects four categories of spending EU funds were distinguished: revaluation of cultural heritage objects, creation and development of a new tourism product, sports and recreation infrastructure and - as one category - promotion, etc.

\section{THE SURVEY AREA}

In the years 2007-2015 the absolute value of the projects co-financed from the European Union funds and related to cultural heritage at the national level in Poland amounted to PLN 12.3 billion, of which PLN 2.5 billion were spent in rural areas, and a further PLN 2.3 billion were spent in rural districts. It follows from the above that the absolute value of 'cultural' projects implemented in the communes, small towns and rural districts, that is to say, in areas functionally related to the countryside, constituted approximately $39 \%$ of the value of all completed projects. In both rural areas (Fig. 1) and rural districts (Fig. 2) differences were observed between voivodships in terms of the absolute value, the amount of EU funding and the structure of the objectives of 'cultural' projects carried out in these areas.

\footnotetext{
${ }^{2}$ Under the N + 2 role UE 2007-2013 may be spent by the of 2015.

${ }^{3}$ Portal Funduszy Unijnych website https://www.funduszeeuropejskie.2007-2013.gov.pl.
} 


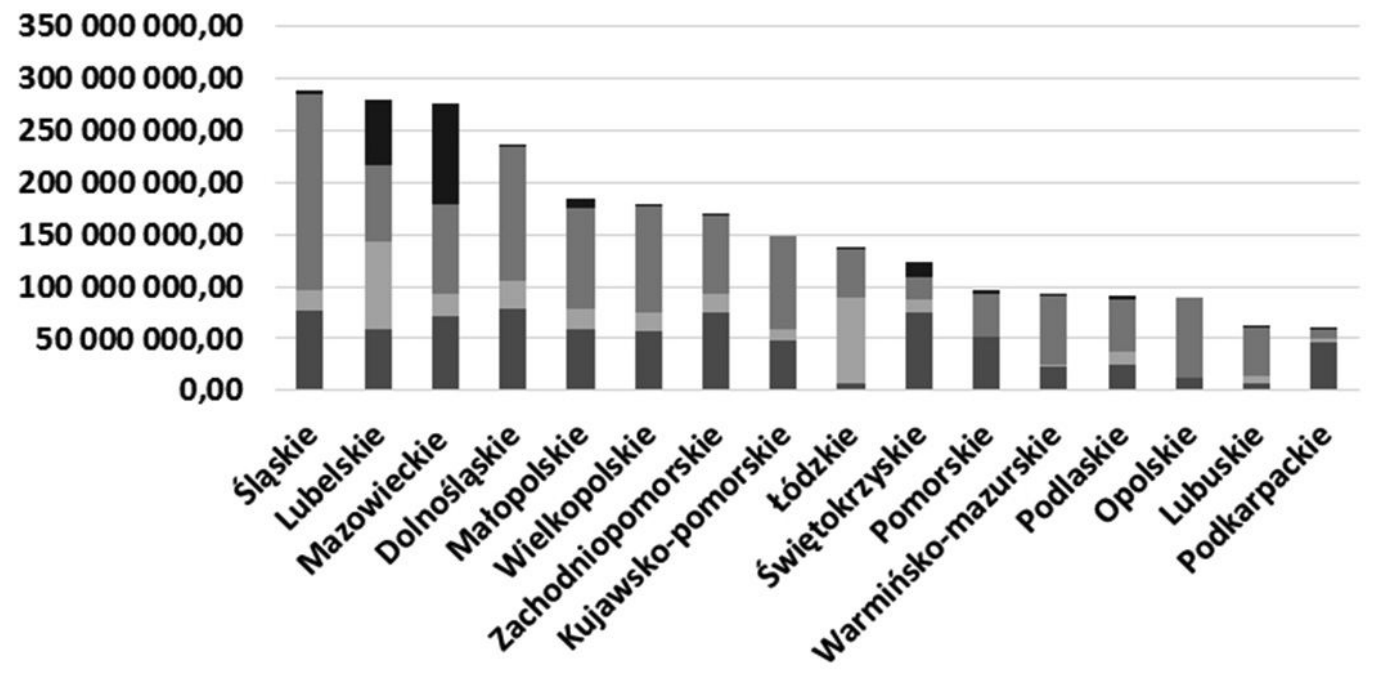

\section{Revalorization of the objects of culture ${ }^{\square}$ The tourism product \\ @ Sports and recreational infrastructure $\quad$ Promotion and others}

Figure 1. The absolute value of 'cultural' projects co-funded from European sources and implemented in rural areas during the period 2007-2013 (15) by voivodship, taking into account purposes of the projects (PLN thousand)

Source: author's calculations based on KSI SIMIK 07-13 as of 31 December 2015.

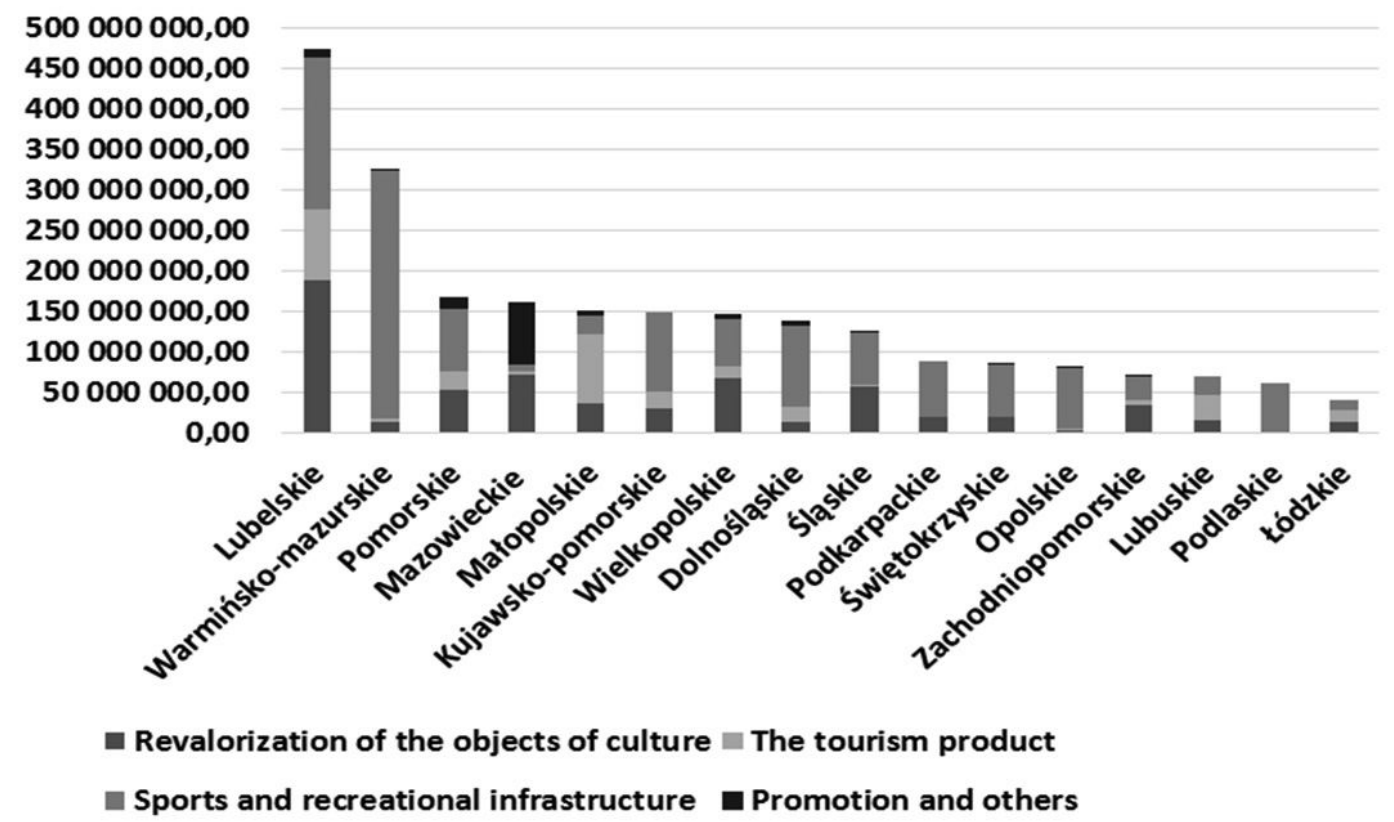

Figure 2. The absolute value of 'cultural' projects co-funded from European sources and implemented in rural districts during the period 2007-2013 (13) by voivodship, taking into account purposes of the projects (PLN thousand)

Source: author's calculations based on KSI SIMIK 07-13 as of 31 December 2015.

In terms of the absolute value of cultural projects implemented in rural areas, that is to say, in communes and small towns, three groups of voivodships can be distinguished (Fig. 1). Group one comprises Śląskie, Lubelskie, Mazowieckie and Dolnośląskie
Voivodships, in which the absolute value of funds spent on 'cultural' projects ranged from PLN 200 million to PLN 300 million; in each of the voivodships of the second group (Małopolskie, Wielkopolskie, Zachodniopomorskie, Kujawsko-Pomorskie 
and Świętokrzyskie), the absolute value of completed 'cultural' projects ranged from PLN 100 million to 200 million, and in the third group of voivodships (Pomorskie, Warmińsko-Mazurskie, Podlaskie, Opolskie, Lubuskie and Podkarpackie) this value was below PLN 100 million.

As regards rural districts, two groups of voivodships can be identified (Fig. 2). Group one includes voivodships (Lubelskie, Warmińsko-Mazurskie) in which the absolute value of completed 'cultural' projects ranging from PLN 300 million to 450 million was many times higher than that in the remaining voivodships, which should be regarded as group two. When the expenditures in rural areas and in rural districts are considered together, one can see that most of the funds were definitely obtained by the areas related to the countryside in the Lubelskie Voivodship (a total of more than PLN 750 million). In the Mazowieckie, Warmińsko-Mazurskie, Śląskie, Dolnośląskie, Małopolskie and Wielkopolskie Voivodships the value of completed 'cultural' projects in the rural environment during the period 2007-2015 was also significant (ranging between PLN 300 million and 450 million). However, in the remaining voivodships areas which were functionally related to the countryside benefited the least. The result obtained shows no regional dependencies, but it seems to be the effect of the impact of the potential of cultural assets in the regions.

When analysing the way of spending funds according to the objectives of completed projects, one should point to a high share, in both rural areas and rural districts, of the absolute value in expenditures related to the development of infrastructure and restoration of cultural assets; however, there were fewer projects thematically related to the creation of a new tourism product and promotion. Apparently, such a structure of expenditure within the framework of cultural projects is a reflection of current needs of the rural environment in which beneficiaries strive in the first place to improve living conditions in the countryside and, what is equally important, to restore and preserve traditional values.

The value of EU funding for 'cultural' projects carried out at the national level in Poland during the period 2007-2015 totalled about PLN 6 million, which constituted almost $49 \%$ of their absolute value. On the other hand, in rural areas and rural districts the share of EU co-financing was higher and it totalled around $52 \%$ of completed projects in each one of them. When noting the increased financial support from the EU for 'cultural' projects in the rural environment one should also point to certain regional differences in this respect.

Entities in the Ślaskie Voivodship achieved the highest rate of co-financing for culture-related projects implemented in rural areas (Fig. 3). It is worth noting that in the Silesian region the highest EU co-financing rate was observed in the case of projects relating to tourism product and promotion, while in the case of projects pertaining to reconstruction of cultural heritage assets and infrastructure this rate was relatively lower, which clearly differed from the structure of EU funding for 'cultural' projects at the level of rural areas across Poland. Equally high level of EU funding for culture-related projects implemented in rural areas was recorded in the Mazowieckie, Lubelskie and Dolnośląskie Voivodships. In Mazowieckie and Dolnośląskie Voivodships very high rates were reported in the case of projects concerning the reconstruction of cultural heritage assets, while in the Lubelskie Voivodship the infrastructure was of particular importance. It should also be mentioned that in the Dolnośląskie and Lubelskie Voivodships projects relating to promotion received a very high level of financial support. This is undoubtedly related to the fact that the capitals of these voivodships applied for being the capital of culture in 2016 .

In the case of the remaining voivodships, just as in rural areas throughout Poland, the largest EU grants went to support the projects thematically related to the restoration of cultural heritage; there were also very important projects supporting the creation of a new tourism product, and, subsequently, development of infrastructure and promotion. When comparing Figure 3 with Figure 1 and with Table 1, one can find some differences in the preference of spending targets of EU funds between beneficiaries and decision-makers responsible for spending funds at European level. Local entities gave preference to the development of infrastructure and reconstruction of cultural heritage, while policy-makers in the European Union allocated the greatest amount of funding for cultural heritage 


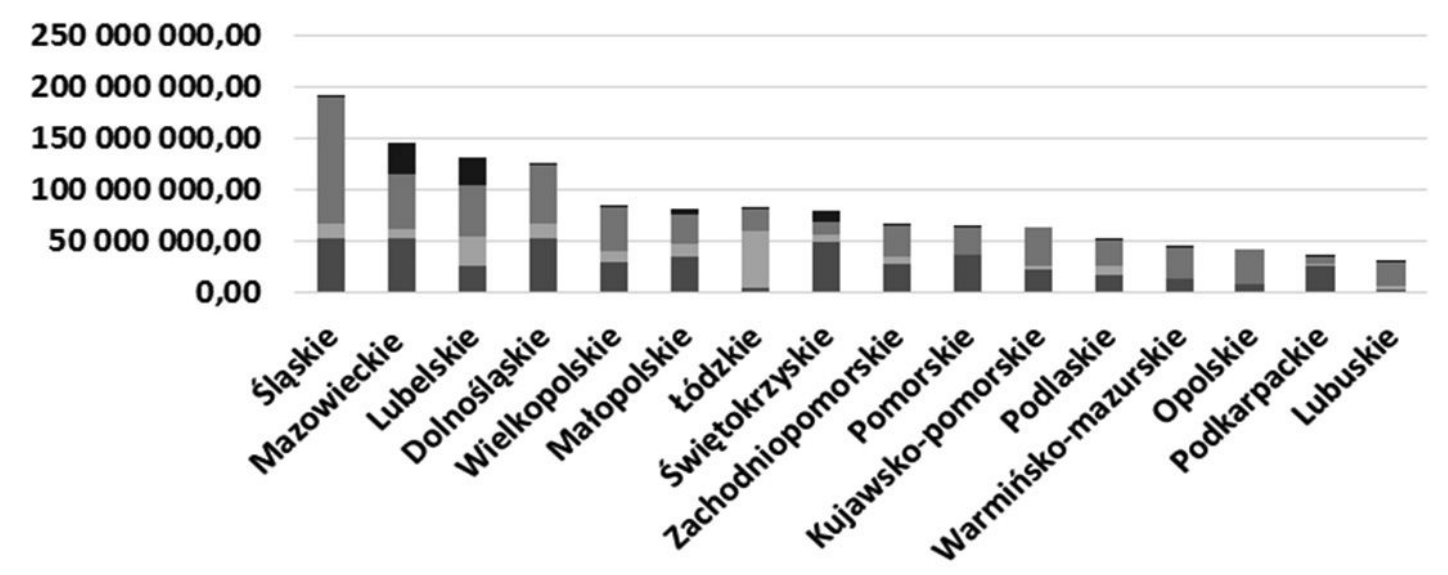

Eevalorization of the objects of culture $=$ The tourism product

- Sports and recreational infrastructure Promotion and others

Figure 3. Co-financing from EU funds for 'cultural' projects co-funded from European sources and implemented in rural areas during the period 2007-2013 (15) by voivodship, taking into account purposes of the projects (thousand PLN)

Source: author's calculations based on KSI SIMIK 07-13 as of 31 December 2015.

Table 1. Co-financing from EU funds for 'cultural' projects co-funded from European sources and implemented in rural districts during the period 2007-2013 (15) by voivodship, taking into account purposes of the projects $(\%)$

\begin{tabular}{|l|c|c|c|c|c|}
\hline Voivodship & $\begin{array}{c}\text { Revalorization } \\
\text { of the objects of } \\
\text { culture }\end{array}$ & $\begin{array}{c}\text { The tourism } \\
\text { product }\end{array}$ & $\begin{array}{c}\text { Sports } \\
\text { and recreational } \\
\text { infrastructure }\end{array}$ & $\begin{array}{c}\text { Promotion and } \\
\text { others }\end{array}$ & Totally \\
\hline Pomorskie & 70.65 & 84.85 & 68.00 & 42.76 & 68.37 \\
\hline Śląskie & 68.65 & 74.20 & 64.32 & 79.84 & 66.29 \\
\hline Świętokrzyskie & 65.96 & 65.16 & 51.08 & 75.13 & 64.29 \\
\hline Lódzkie & 67.96 & 66.51 & 45.94 & 70.97 & 59.68 \\
\hline Podkarpackie & 56.55 & 65.73 & 70.76 & 27.14 & 58.69 \\
\hline podlaskie & 69.56 & 74.40 & 48.11 & 77.69 & 58.44 \\
\hline Dolnośląskie & 67.86 & 51.66 & 44.40 & 66.05 & 53.17 \\
\hline Mazowieckie & 73.25 & 47.69 & 61.31 & 30.13 & 52.40 \\
\hline Warmińsko-Mazurskie & 59.69 & 70.61 & 45.82 & 84.63 & 49.88 \\
\hline Lubuskie & 57.87 & 43.50 & 48.79 & 29.94 & 48.96 \\
\hline Lubelskie & 45.51 & 33.78 & 67.00 & 43.52 & 47.08 \\
\hline Wielkopolskie & 53.40 & 58.95 & 40.19 & 84.54 & 46.69 \\
\hline Opolskie & 71.42 & - & 42.42 & - & 46.43 \\
\hline Małopolskie & 60.33 & 64.81 & 28.73 & 60.77 & 44.33 \\
\hline Kujawsko-Pomorskie & 45.89 & 37.79 & 42.30 & - & 43.17 \\
\hline Zachodniopomorskie & 37.47 & 36.99 & 41.78 & 54.77 & 39.36 \\
\hline Poland & 59.89 & 53.19 & 49.61 & 41.85 & 52.63 \\
\hline
\end{tabular}

Source: author's calculations based on KSI SIMIK 07-13 as of 31 December 2015. 
assets and for the creation of a new tourism product. Thus, one may say that local entities attached the greatest importance to the current needs of local communities (infrastructure), and, secondly, to the preservation of cultural heritage. On the other hand, decision-makers at European level attached the greatest importance to the implementation in rural areas of those projects which directly took into account cultural objectives. At the same time, through the support from the European level for projects relating to the creation of new tourism products one may suppose that special support was provided to local entrepreneurship.

The largest EU funds for 'cultural' projects carried out in rural districts (Fig. 4), ranging from PLN 200 million to 250 million, were recorded in the Lubelskie and Warmińsko-Mazurskie Voivodships. In both voivodships the main aim of EU co-funding was the development of tourism infrastructure, and in the Lubelskie Voivodship the main focus was also on projects thematically related to the reconstruction of cultural heritage. In the group of voivodships in which EU funding ranged from PLN 50 million to 100 million (Pomorskie, Mazowieckie, Śląskie,
Kujawsko-Pomorskie, Wielkopolskie, Małopolskie and Dolnośląskie) the greatest grants were also recorded in the case of projects aimed at the development of infrastructure, and, secondly, the restoration of cultural heritage. A clearly different structure of the amount of EU funding, depending on the targets, was observed in the Mazowieckie Voivodship, where rural districts received substantial funding for the promotion of the region.

Voivodships classified as the third group (Świętokrzyskie, Podlaskie, Zachodniopomorskie, Opolskie, Lubuskie, Łódzkie and Podkarpackie) obtained less than PLN 50 million funding from the EU for the implementation of culture-related projects. Financing structure varied greatly in these voivodships, while maintaining the dominance of infrastructure (Fig. 4). It is worth noting that in rural districts there was a very high rate of the share of EU co-funding relative to the overall value of the projects which aimed at promoting the regions, although gross expenditure for this purpose was relatively small (Table 1). By comparing Figure 4 with Figure 2 and with Table 2, one should note that both local beneficiaries

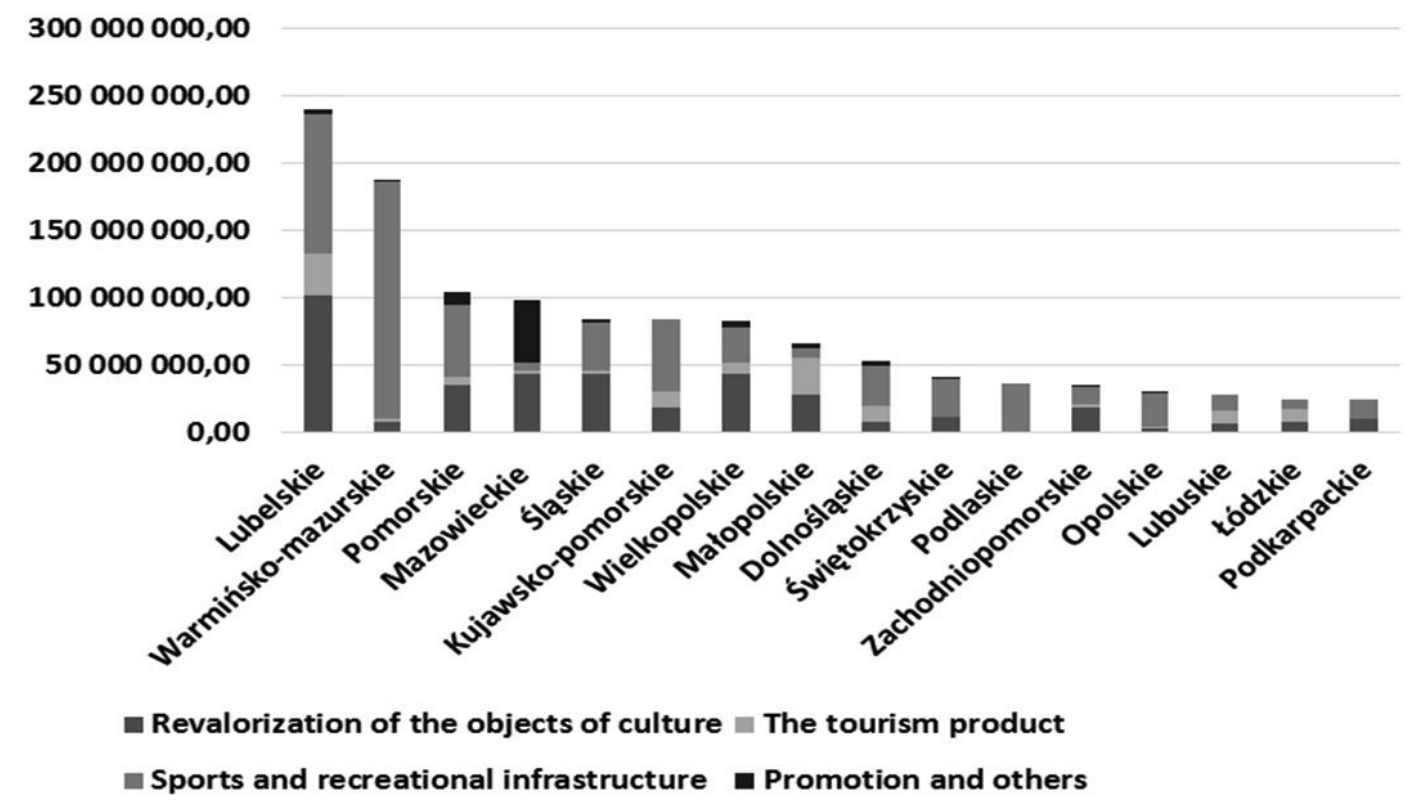

Figure 4. The level of co-financing from EU funds for 'cultural' projects co-funded from European sources and implemented in rural areas during the period 2007-2013 (15) by voivodship, taking into account purposes of the projects (thousand PLN)

Source: author's calculations based on KSI SIMIK 07-13 as of 31 December 2015. 
Proceedings of the 2018 International Scientific Conference 'Economic Sciences for Agribusiness and Rural Economy' No 1, Warsaw, 7-8 June 2018, pp. 335-342

Table 2. The level of co-financing from EU funds for 'cultural' projects co-funded from European sources and implemented in rural districts during the period 2007-2013 (15) by voivodship, taking into account purposes of the projects $(\%)$

\begin{tabular}{|l|c|c|c|c|l|}
\hline Voivodship & $\begin{array}{c}\text { Revalorization } \\
\text { of the objects } \\
\text { of culture }\end{array}$ & Tourism product & $\begin{array}{c}\text { Sports and } \\
\text { recreational } \\
\text { infrastructure }\end{array}$ & $\begin{array}{c}\text { Promotion and } \\
\text { others }\end{array}$ & Totally \\
\hline Śląskie & 76.56 & 57.38 & 55.75 & 84.60 & 65.64 \\
\hline Pomorskie & 63.98 & 28.34 & 69.29 & 64.87 & 61.70 \\
\hline Mazowieckie & 60.30 & 46.06 & 64.06 & 60.44 & 60.19 \\
\hline Lódzkie & 53.56 & 67.43 & 56.75 & - & 59.35 \\
\hline Warmińsko-Mazurskie & 53.33 & 71.14 & 57.43 & 72.25 & 57.45 \\
\hline Podlaskie & 55.29 & - & 56.71 & - & 56.69 \\
\hline Wielkopolskie & 63.53 & 53.76 & 46.34 & 83.69 & 56.68 \\
\hline Kujawsko-Pomorskie & 61.04 & 56.60 & 54.60 & $*$ & 56.20 \\
\hline Lubelskie & 53.65 & 35.77 & 55.15 & 34.89 & 50.54 \\
\hline Zachodniopomorskie & 50.09 & 48.97 & 46.78 & 50.82 & 48.63 \\
\hline Świętokrzyskie & 56.96 & 58.09 & 44.71 & 47.31 & 47.61 \\
\hline Małopolskie & 73.87 & 32.97 & 29.96 & 61.39 & 43.55 \\
\hline Lubuskie & 42.95 & 29.44 & 49.98 & - & 38.85 \\
\hline Dolnośląskie & 53.36 & 66.35 & 29.76 & 60.81 & 37.98 \\
\hline Opolskie & 63.36 & 78.42 & 34.48 & 81.13 & 36.96 \\
\hline Podkarpackie & 47.80 & - & 20.34 & - & 26.91 \\
\hline Poland & 59.30 & 40.38 & 49.87 & 60.48 & 51.79 \\
\hline Sorce: & & & & - & \\
\hline
\end{tabular}

Source: author's calculations based on KSI SIMIK 07-13 as of 31 December 2015.

and European policy-makers preferred the development of infrastructure and the reconstruction of cultural heritage, the share of other objectives being lower. As regards rural districts, the highest level of EU co-financing was recorded in the Śląskie Voivodship (more than 65\%) and in Pomorskie, Mazowieckie, Łódzkie and Warmińsko-Mazurskie Voivodships (approximately 60\% for each one of them).

On the other hand, the lowest level of co-funding for 'cultural' European projects carried out at the level of rural districts was reported in the Małopolskie, Lubuskie, Dolnośląskie, Opolskie and Podkarpackie Voivodships. One can distinguish a group of voivodships in which a high activity was observed, both at the level of rural areas and rural districts, in the field of the implementation and acquisition of European funds for culture. These are: Mazowieckie, Śląskie, Lubelskie, Wielkopolskie and Małopolskie Voivodships.

\section{CONCLUSIONS}

The analysis conducted in the paper leads to the following conclusions.

In the years 2007-2015, both in terms of the absolute value and the structure, depending on the objectives of implemented 'cultural' projects, no regional dependencies were recorded, while the differentiation of the phenomenon was influenced by the cultural potential of the regions. 
In terms of the absolute value of 'cultural' projects carried out in the rural environment the highest share was observed, in both rural areas and rural districts, in the case of those projects which were aimed at developing infrastructure and restoring cultural heritage assets, while projects thematically related to the creation of a new tourism product and promotion were of lesser importance. This structure of expenditures under "cultural" projects indicates that local beneficiaries, while using EU funds, sought primarily to improve living conditions in the rural environment, not forgetting, at the same time, about the preservation of traditional values.

However, the highest grants from EU sources were provided for projects thematically related to the reconstruction of cultural heritage and creation of tourism products, which shows that the activities aimed at preservation of cultural heritage and support for local entrepreneurship are of particular significance to European entities. At the same time, it should be noted that EU funding for 'cultural' projects carried out in the areas which are functionally related to the rural environment was higher than that in Poland as a whole.

\section{REFERENCES}

1. Biczkowski, M. (2016). Fundusze unijne wdrażane poprzez regionalne programy operacyjne jako neoendogeniczny czynnik rozwoju obszarów wiejskich [EU Funds implemented by the regional operational programmes as neo-endogenous development factor for rural areas]. Studia Obszarów Wiejskich, 41, pp. 63-81.

2. Cawley, M., Gillmor, D.A. (2008). Integrated Rural Tourism: Concepts and Practice. Annals of Tourism Research, 35 (2), pp. 316-33.

3. Courtney, P., Errington, A. (2000). The Role of Small Towns in the Local Economy and Some Implications for Development Policy. Local Economy, 15 (4), pp. 280-301.

4. Gralak, A., Powęska, H., (2017). The utilization of EU funds in the years 2007-2015 for the preservation of cultural heritage of rural areas in Eastern Poland. Acta Scientiarum Polonorum Oeconomia, 16 (2), pp. 55-64.

5. Gralak, K. (2009). Funkcja turystyczna i jej znaczenie dla rozwoju lokalnego i regionalnego [Tourism function and its importance for local and regional development]. In: Powęska, H. (ed.) Sposoby wykorzystania dóbr kultury dla potrzeb rozwoju funkcji turystycznej na Mazowszu przy wsparciu z funduszy strukturalnych [Ways of using cultural goods to develop the tourism function in Mazovia with the support of structural funds]. Wydawnictwo SGGW, Warszawa, pp. 22-35.

6. Heffner, K. (2016). Obszary wiejskie i małe miasta: czy lokalne centra są potrzebne współczesnej wsi? [Small towns and rural areas. Do local centres needed by contemporary countryside?]. Studia Ekonomiczne. Zeszyty Naukowe Uniwersytetu Ekonomicznego w Katowicach, 279, pp. 11-22.

7. Hełpa-Liszkowska, K. (2013). Dziedzictwo kulturowe jako czynnik rozwoju lokalnego [Cultural Heritage as a Factor of Local Development]. Studia Oeconomica Posnaniensia, 1, 6 (255), pp. 5-18.

8. Ilczuk, D. (2014). Ekonomika kultury [Cultural economics]. Wydawnictwo Naukowe PWN, Warszawa.

9. Kałuża, H. (2011). Fundusze unijne w procesie aktywizacji obszarów wiejskich - stadium przypadku [European Union funds in the process of activation of rural areas - a case study]. Zeszyty Naukowe SGGW w Warszawie. Problemy Rolnictwa Światowego, 11 (26), Vol. 1, pp. 73-80.

10. MacDonald, R., Jolliffe, L. (2002). Cultural Rural Tourism: Evidence from Canada. Annals of Tourism Research, 30 (2), pp. 307-322.

11. Murzyn-Kupisz, M. (2012). Dziedzictwo kulturowe a rozwoj lokalny [Cultural Heritage and Local Development]. Wydawnictwo Uniwersytetu Ekonomicznego w Krakowie, Kraków.

12. Pondel, H. (2017). Fundusze Unii Europejskiej jako czynnik wspierający zrównoważony rozwój obszarów wiejskich [European Union Funds as a Factor Supporting the Sustainable Development of Rural Areas]. Studia Oeconomia Posnaniensia, 5 (5), pp. 88-102.

13. Powęska, H. (2016). Categorisation of products of projects carried out in Lubelskie voivodship in the field of cultural assets co-financed under operational programs 2007-2013(2015). Roczniki Naukowe Stowarzyszenia Ekonomistów Rolnictwa i Agrobiznesu, 18 (4), pp. 196-201.

14. Ustawa $\mathrm{z}$ dnia 15 lutego 1962 r. o ochronie dobr kultury [Act of 15 February 1962 concerning the protection of cultural assets]. Journal of Laws 1962 item 48. 